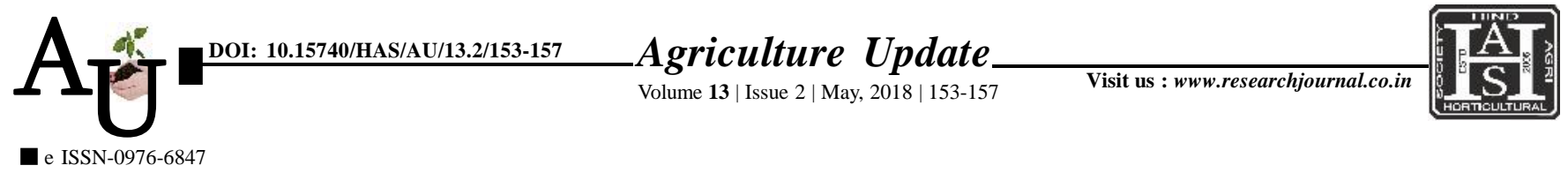

\title{
Research Article: Assessment of socio-economic status of MGNREGA women beneficiaries, Baran district (Rajasthan)
}

Priyanshu Tripathi and Nikita Wadhawan

Article Chronicle :

Received :

14.02.2018;

Revised :

20.03.2018;

Accepted :

06.04.2018

KEY WoRDS : MGNREGA, Socioeconomic status, Women beneficiaries

Author for correspondence :

Priyanshu Tripathi Department of Food and Nutrition, College of Home Science,

Maharana Pratap

University of Agriculture Technology, Udaipur (Rajasthan) India Email:tripathipriyu89@ gmail.com

See end of the article for authors' affiliations
SUMMARY : MGNREGA is an ambitious scheme providing employment to rural people of India. The basic aim of Mahatma Gandhi National Rural Employment Guarantee Act is to enhance livelihood security of household in rural area. By this scheme Govt. gives assurance of employment to unskilled rural laborer for 100 days. With better implementation such type of scheme may be an effective weapon to fight against poverty. It also aims at transforming the rural areas by improving the socio-economic conditions of people. The present study was undertaken with the objective to assess the socioeconomic status of MGNREGA women beneficiaries in Baran district of Rajasthan. Five villages namely Laxmipura, Chainpura, Ratanpura, Govindpura and Khedliganj from Atru Panchayat Samiti were identified for the study. Twenty five women beneficiaries from each village were selected making a total of 125 women beneficiaries. All respondents selected for the study were in the age group 30-45 years. Majority of the respondents $(86.4 \%)$ were married and rest of them (13.6\%) widow. Most of respondents who come for MGNREGA work belonged to schedule caste and schedule tribe (57.6\%), backward caste (25.6\%) and a small number were from general caste (2.4\%). Maximum numbers of respondents (86.4\%) were working as farm labour. Fifty eight per cent respondents were from nuclear family and rest of them (42.4\%) belonged to joint family. Regarding education a high percentage respondents (91.2\%) were illiterate and had no any organizational membership. Majority of respondents $(72.8 \%)$ were landless, whereas 18.4 per cent had land upto 4.5 bighas. Most of them (53.6\%) reside in Kachaha house. Calculation of socio-economic status (AICRP-HECM 1998) revealed that all respondents (100\%) belonged to low socio-economic status.

How to cite this article : Tripathi, Priyanshu and Wadhawan, Nikita (2018). Assessment of socio-economic status of MGNREGA women beneficiaries, Baran district (Rajasthan). Agric. Update, 13(2): 153-157; DOI : 10.15740/HAS/AU/13.2/153-157. Copyright@2018: Hind Agri-Horticultural Society. 